\title{
Marcadores da paisagem e intervenção cadastral no território próximo da cidade de Bracara Augusta (Hispania Citerior Tarraconensis)
}

\author{
Landscape markers and cadastral intervention \\ in the territory near Bracara Augusta \\ (Hispania Citerior Tarraconensis)
}

\section{Marcadores de paisaje e intervención catastral en el territorio próximo a Bracara Augusta (Hispania Citerior Tarraconensis)}

\author{
Helena Paula Carvalho \\ Universidade do Minho (Portugal)
}

RESUMO

Este artigo propõe-se apresentar os resultados do estudo do povoamento e da organização da paisagem em torno da cidade romana de Bracara Augusta. Este objectivo orienta-se, mais especificamente, para os dados relativos à identificação de um cadastro romano perfeitamente adaptado às formas estruturantes do relevo e da rede hidrográfica. Este cadastro possui uma orientação de cerca de $16^{\circ} \mathrm{NNO}$ com uma modulação de 20x20 actus, e encontra-se confirmado por alguns elementos demarcatórios, nomeadamente dois cipos que possuem entre si 20 actus de distância.

\section{SUMMARY}

This paper focuses the organization of the rural landscape around the Roman town of Bracara Augusta and the identification of a Roman cadastre, perfectly adapted to the relief and to the main hydrographical network of the region. This cadastre is organized in modules of 20 by 20 actus with a predominant orientation of $16^{\circ} \mathrm{NNW}$, what may be inferred by the clear intersection of some important axes. We have also detected two cippi with a cross engraved on their upper face, separated by 20 actus, probably connected with limits or termini.

\section{RESUMEN}

Este trabajo tiene como objetivo presentar algunos de los resultados del estudio sobre el poblamiento y la organizacion del paisaje rural en torno a la ciudad romana de Bracara Augusta. La existencia de un cadastro romano con una orientación dominante de $16^{\circ} \mathrm{NNO}$ y una modulación de 20x20 actus, se confirma gracias a la documentación de algunos ele- mentos de delimitación, de los que podemos destacar dos cipos con una distancia entre sí de 20 actus.

PALAVRAS-CHAVE: Arqueologia da paisagem, Povoamento, Cadastro romano, Termini antiqui.

KEY WORDS: Landscape archaeology, Rural settlement, Roman cadastre, Termini antiqui.

PALABRAS CLAVES: Arqueologia del paisaje, Poblamiento rural, Cadastro romano, Termini antiqui.

\section{INTRODUÇÃO}

A fundação de Bracara Augusta, a sua evolução urbana e os contornos da sua inserção no espaço rural constituem um horizonte de investigação decisivo para o conhecimento da romanização da Hispânia. O papel exercido pela cidade na organização da paisagem envolvente e os circuitos de relação e interferência estabelecidos entre ambos determinaram o objectivo do trabalho que aqui apresentamos: averiguar em que medida se desencadearam processos de organização e demarcação territorial na periferia imediata de Bracara Augusta.

Abordaremos, inicialmente, as características principais do urbanismo de Braga romana e a cartografia dos dados arqueológicos que ajudam a definir a 


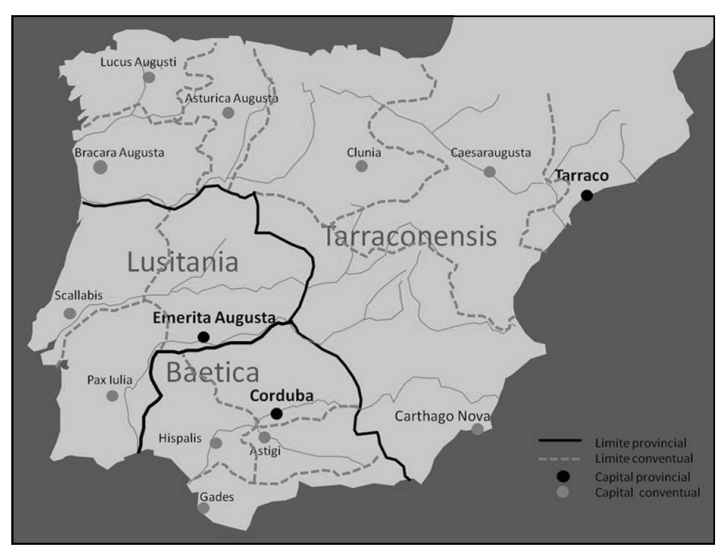

Figura 1. Localização de Bracara Augusta na Hispânia Romana.

presença romana na paisagem envolvente (a rede viária principal, as necrópoles e os indícios de povoamento). A nossa atenção centrar-se-á, de seguida, nos dados referentes à análise do parcelamento rural que permitiram identificar a existência de uma centuriação.

\section{IMPLANTAÇÃO DA CIDADE}

Bracara Augusta é, tanto quanto os dados arqueológicos permitem afirmar, uma fundação ex nihilo da época de Augusto (Fig. 1).

A escolha do local para instalar a cidade deverá ter sido determinada por duas circunstâncias essenciais: a sua posição relativamente aos povoados indígenas e, não menos importante, a sua centralidade relativamente aos eixos de comunicação pré-romanos, que permitiam uma articulação eficaz com a costa atlântica, o Noroeste peninsular e o mundo já controlado do Sul da Península (Martins 1999; Lemos 2002; Morais 2005).

Bracara Augusta foi implantada numa plataforma com cerca de 200 metros de altitude, situada no interflúvio dos rios Cávado e Este. Uma série de relevos significativos, com altitudes máximas entre os 500 e 600 metros, enquadra esta plataforma e as veigas circundantes (Teixeira e Medeiros 1973). Do ponto de vista geológico, este território é dominado por rochas graníticas e pela ocorrência de algumas rochas metassedimentares (Ferreira et alii 2000). As variações do relevo ligam-se directamente com a tectónica, pois a fracturação hercínica NNE/SSW e NW/SE marcou definitivamente, quer a litologia, quer o relevo da região. Posteriormente, os movimentos alpi- nos criaram uma outra rede de fracturas ENE/WSW. Às últimas fases da fracturação hercínica deve-se a instalação sucessiva de uma grande variedade de granitóides, que correspondem a mais de $80 \%$ do suporte rochoso da área. Este substrato dominante forneceu um material de construção de primeira grandeza, tendo sido intensamente explorado. Regista-se a ocorrência de importantes áreas de barreiros. $\mathrm{Na}$ época romana, é seguro o aproveitamento das argilas da região do médio Cávado, explorado em torno da zona de Prado, Cabanelas e Ucha, sendo igualmente certa a exploração de caulinos presentes na zona litoral, estes últimos usados na produção de cerâmica fina (Morais 2005).

A consulta dos primeiros fotogramas aéreos em contraste com as imagens actuais permite uma percepção rápida do crescimento acelerado da cidade e das drásticas alterações no meio envolvente nas últimas décadas. Nos fotogramas dos anos 40 do século $\mathrm{xx}$, o mundo rural parecia ainda invadir a cidade, não sendo clara a definição dos limites entre ambos. A dificuldade mantém-se nas imagens actuais, mas por razões inversas. De facto, a cidade parece estar a "consumir", com muita rapidez, o seu tradicional espaço rural, facto que torna cada vez mais difícil o estudo das formas e organização da paisagem.

\section{URBANISMO DE BRACARA AUGUSTA}

Bracara Augusta conheceu, desde muito cedo, um dinamismo comercial considerável, conforme pode ser demonstrado pela epigrafia, pelas importações presentes na cidade e pela própria produção local que alimentava certamente a região (Morais 2005; Cruz 2001; 2009). A densidade e o grau de desenvolvimento das comunidades pré-romanas da região onde a cidade se implanta podem explicar a predominância do meio indígena na composição social da cidade, com escassa representação de cidadãos romanos e militares e a presença dominante de peregrinos, libertos e escravos, panorama que está também presente na área rural (Tranoy 1981; Santos, Le Roux e Tranoy 1983; Tranoy e Le Roux 1989-1990).

Os trabalhos arqueológicos desenvolvidos nas últimas décadas reconstituíram uma malha ortogonal, orientada segundo eixos de orientação NNO/SSE e SOO/NEE, recuperada a partir de muros, cloacas e de infra-estruturas viárias e de circulação como ruas e pórticos (Martins e Delgado 1989-90; Lemos e Leite 2000; Martins 2000; 2004; Ribeiro 2008; Martins e Fontes 2010; Ribeiro 2010; Magalhães 2010; Martins 2011) (Fig. 2). 


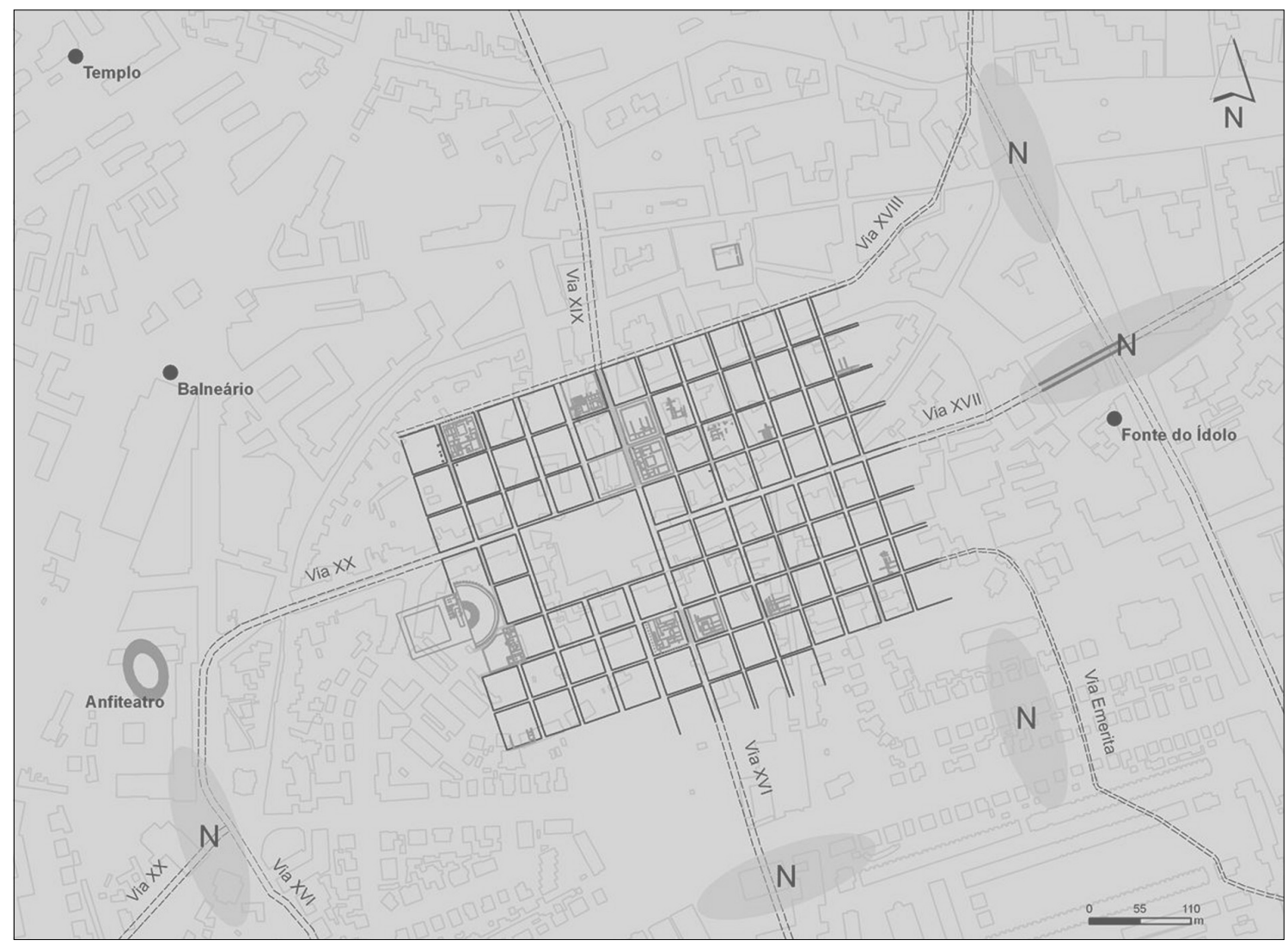

Figura 2. Bracara Augusta: malha urbana, localização das necrópoles e saída das principais vias romanas (Martins et alii 2012).

A cartografia dos alinhamentos correspondentes ao plano ortogonal da cidade sugere que a área planificada não abarcou a totalidade da urbe que viria a ser defendida pela muralha baixo-imperial. ${ }^{1}$ Esta muralha terá sido construída em finais do século III - inícios do século Iv, definindo uma área de 48 hectares que sabemos ter deixado de fora algumas construções da cidade anterior. De facto, foram detectadas construções com alinhamentos dissonantes dos eixos da malha urbana, alguns dos quais associados a áreas artesanais que podem ter-se desenvolvido na periferia do núcleo original planificado, ampliando, assim, a cidade.

\footnotetext{
${ }^{1}$ Refira-se que os limites da cidade foram sempre desenhados em função de uma muralha referida em documentos dos séculos XII e XIII, cujas evidências foram descritas por vários eruditos locais entre os séculos XVII e XVIII (Cunha 16341635; Argote 1732-1734). Em 1910, J. Teixeira elaborou uma primeira planta da área urbana de Braga circunscrita pela muralha (Oliveira 1978). Este traçado tem vindo a ser genericamente confirmado pelas escavações realizadas nas últimas décadas no âmbito do projecto de Bracara Augusta (Martins 2004; Ribeiro 2008).
}

Tal como se verifica nas duas outras cidades de fundação augústea e capitais conventuais no Noroeste (Lucus Augusti e Asturica Augusta), também em Bracara Augusta se regista um importante surto urbanístico a partir da época flávia, panorama que se mantém durante o século II. Com efeito, a maioria dos edifícios conhecidos está datada do período flávio ou flávio-antonino, circunstância que se poderá explicar, precisamente, pela profunda renovação ocorrida entre o último quartel do século I e meados do século II. Importa, neste contexto, salientar que a dinâmica empreendida terá desmantelado ou camuflado muitos dos vestígios arquitectónicos mais significativos do período precedente, o que, se não for convenientemente lido, projecta uma inevitável distorção cronológica na avaliação da evolução urbana.

Em inícios do século II foi construído o complexo termal público do Alto da Cividade, que reaproveitou materiais e formas de um edifício preexistente, avaliado como pré-termal, de cronologia fundacional ou júlio-cláudia, o qual foi parcialmente arrasado para dar origem a novos edifícios (Silva 2002; Martins 
2004, 2005, 2011; Martins et alii 2011). No terreno adjacente às termas foi implantado um teatro, cuja construção é coeva do edifício termal. Termas e teatro encontram-se perfeitamente articulados e possuem uma notável localização, situando-se na plataforma mais elevada da cidade romana, muito perto do local onde se supõe que estaria localizado o forum (Martins et alii 2006; Martins e Fontes 2010; Ribeiro 2010; Martins 2011). Aceitando a localização proposta para o anfiteatro, sugerida pela análise da fotografia aérea, mas, também, por descrições do mesmo feitas por antiquários e eruditos locais (Morais 2001), teremos um segundo edifício de espectáculos, implantado numa plataforma de altitude inferior à da colina do Alto da Cividade, no alinhamento do decumanus máximo ocidental e, aproximadamente, no eixo do próprio teatro, edificado na vertente da colina referida. $\mathrm{O}$ alinhamento destes edifícios de espectáculos, que se situariam, por sua vez, no eixo do forum, conferia a Bracara Augusta, uma cenografia ajustada aos protótipos de monumentalidade característicos das cidades romanas (Martins 2004).

No espaço da actual Sé catedral foi identificado um outro edifício público, também ele datado do período flávio, interpretado como um macellum, mas cuja planta oferece ainda algumas dificuldades de interpretação. A existência de um mercado naquele local é igualmente sugerida pela descoberta de uma inscrição dedicada ao Genius Macelli, por Flavius Urbicio (Fontes et alii 1997-1998).

No âmbito da arquitectura privada, a escavação da domus das Carvalheiras revelou-se fundamental para a compreensão quer do urbanismo, quer das características da arquitectura doméstica da cidade. Antes de mais porque permitiu estimar a modulação urbana, pois a escavação exumou a totalidade de um quarteirão residencial, limitado por vias, bem como muros de outros quarteirões contíguos. Para além disso, facultou o reconhecimento de uma habitação com átrio e peristilo que contempla, na zona a sul e a oeste, um conjunto de tabernae abertas aos pórticos que ladeavam as ruas. A habitação foi datada do último quartel do século I, tendo sofrido várias remodelações (Delgado e Lemos 1985; 1986; Martins 1997-1998; 1999; Magalhães 2010).

Do período flávio data, ainda, a construção de uma outra domus identificada nos terrenos anexos ao antigo albergue distrital. As escavações realizadas no local revelaram uma rua de cerca de 25 pés $(7,50 \mathrm{~m})$, separando duas insulae e um cruzamento de ruas que ajudou a confirmar o módulo quadrado com área construída de 1 actus $(120 \times 120$ pés $)$ já identificado nas Carvalheiras. Embora o conjunto edificado nesta insula seja difícil de interpretar, dada a reduzida área escavada, as intervenções efectuadas permitiram identificar uma cloaca romana e confirmar a ideia de uma cidade com ruas ladeadas de pórticos, anexos às tabernae construídas no piso térreo das casas (Lemos e Leite 2000; Martins 1997-98; 2004; Magalhães 2010; Ribeiro 2008; Martins et alii 2012).

Com base nos dados disponíveis, podemos, assim, considerar que Bracara Augusta terá atingido a sua máxima extensão no período antonino. Este facto parece acompanhado por um significativo processo de monumentalização da cidade, desde logo caracterizado pela construção dos dois edifícios de espectáculos acima referidos, para já sem paralelo nas outras capitais de conventos do Noroeste. Embora sem dados que o comprovem, é provável que tal processo tenha afectado igualmente a área cívica do forum, à semelhança do que aconteceu noutras cidades da Hispânia (Martins 2004; Ribeiro 2008; Martins e Fontes 2010; Ribeiro 2010; Martins 2011).

\section{REDE VIÁRIA E NECRÓPOLES}

Uma das intervenções mais significativas de $\mathrm{Au}$ gusto no Noroeste peninsular articula-se com a criação de uma rede de estradas que ligavam o triângulo formado por Lugo, Astorga e Braga, a par, evidentemente, das vias que garantiam a ligação com as restantes regiões da Hispânia. Esta estrutura viária foi consolidada com os imperadores flávios, a partir da segunda metade do século I d.C., sobretudo com a construção da Via Nova, ou Via XVIII (Tranoy 1995 96).

A rede viária da região adequa-se, antes de mais, à disposição do relevo e da rede hidrográfica, basicamente de orientação NE/SO. A estes eixos estruturantes, acrescenta-se um conjunto de outros, cuja orientação NO/SE decorre da organização dos afluentes dos rios que seguem as linhas de "fractura" do relevo e que correspondem a portelas e a passagens de montanha. Nas regiões menos elevadas, a topografia permite uma circulação fácil. Estas zonas concentram-se nas margens dos rios Cávado e Este e nas veigas percorridas pelos seus afluentes. A sudeste da área de Braga, as zonas com altitudes mais baixas estão já inseridas na bacia do rio Ave, que comunica com a zona anteriormente descrita por portelas ou circuitos mais sinuosos de passagens de montanha.

Entroncavam em Braga, pelo menos, seis itinerários principais, cinco dos quais referidos pelo Itinerário de Antonino: a Via XVI, Bracara-Cale-Olisi- 
po; a Via XVII, que fazia a ligação a Astorga por Chaves; a Via XIX, Bracara-Lugo, por Prado, Ponte de Lima, Valença e Tui; a Via XX ou via per loca maritima, com traçado ainda muito discutido; a via (não citada no Itinerário) que fazia a ligação a Emerita Augusta, por Tongobriga e Egitania; a Via XVIII, aberta sob os Flávios, que assegurava a ligação a Astorga pelo coração da principal área mineira do Noroeste (Tranoy 1981; Martins 1990; Mantas 1996; 2000; Lemos 2002; Rodríguez Colmenero et alii 2004).

A saída das vias romanas encontra-se intimamente associada à localização das necrópoles, facto que permite a utilização do espaço das necrópoles como elemento delimitador do espaço urbano e, em alguns casos, supôr, por inferência, tanto esses limites como o traçado de saída das vias. Conhecem-se em Bracara Augusta cinco grandes necrópoles, que podem associar-se à saída dos itinerários anteriormente descritos: a chamada necrópole da Via XVII (Fontes et alii 2008; Martins et alii 2009; Braga 2010), a necrópole de Maximinos, associada à saída da Via XX e eventualmente, também da Via XVI; a necrópole da Rodovia, eventualmente associada ao eixo sul e sudeste da cidade (saída da Via Bracara-Emerita e, ainda, uma das possíveis saídas da Via XVI); a necrópole do Campo da Vinha que nos parece lícito associar à Via XIX, situada a norte da cidade e a necrópole descoberta na parte poente da Avenida Central, associada à via XVIII a nordeste. As necrópoles conhecidas revelam uma cronologia muito ampla, que remonta ao século I e se estende até aos séculos VI/VII (Martins e Delgado 1989-1990; Tranoy e Le Roux 1989-1990; Fontes 1993; Fontes et alii 2008; Martins et alii 2009; Braga 2010).

$\mathrm{O}$ esqueleto viário da região não se resumiria, seguramente, à rede de itinerários principais, incluindo, intensas ramificações em caminhos privados e vicinais. Todas estas condições possibilitavam uma relação estreita entre a cidade e o campo, relação visível na atracção que a cidade parece exercer na distribuição do povoamento da sua área rural circundante.

\section{O POVOAMENTO DE RAÍZ ROMANA}

As características do relevo e da hidrografia da região garantiram uma ocupação humana apreciável, testemunhada na mancha densa de vestígios cartografados (Figs. 3 e 4).

Foi possível detectar a existência de uma clara concentração de ocupação que ocupa uma zona apla- nada e fértil, cobrindo uma área de cerca de $5 \mathrm{~km}$ em torno da cidade. Dentro desta área, a zona a norte apresenta a maior densidade de vestígios, correspondendo à veiga enquadrada pelas áreas montanhosas de Montariol, a leste, e Gondizalves, a oeste. Esta maior concentração de vestígios estende-se igualmente, embora de forma menos intensa, para sul, pela chamada veiga do Penso, até à zona de Lomar e Esporões (Carvalho 2008b).

É, precisamente, nesta área que se verifica a maior concentração de locais identificados como villae. As villae conhecidas possuem em comum uma localização privilegiada nas zonas de veiga, em terras de grande potencial agrícola, com boa exposição solar, abrigadas dos ventos e com acesso a uma rede hidrográfica densa. A sua localização obedece ainda a outros parâmetros comuns, como seja, a sua implantação preferencial em zonas de declive suave ou em pequenos outeiros, cujas altitudes acompanham, maioritariamente, as curvas de nível entre os 50 e os 100 metros. Esta associação de características, reconhecida noutros contextos do Noroeste peninsular (Pérez Losada 1987; 1996), permitiria a estes estabelecimentos uma economia de policultura, que serviria o autoconsumo, mas também a produção de excedentes necessários ao abastecimento da cidade (Martins 1995; Carvalho 2008b). A atracção exercida por Bracara Augusta em relação à implantação de estabelecimentos de tipo villa verifica-se na mancha de vestígios atribuídos a esta categoria de sítios, registada numa área que, grosso modo, compreende um aro de $5 \mathrm{~km}$ em torno da cidade. Importa salientar, ainda, a sua proximidade relativamente aos eixos viários que terão condicionado a organização do habitat.

A tendência geral observada relativamente à localização preferencial de pequenos estabelecimentos agrícolas, sugeridos basicamente por manchas de vestígios cerâmicos, revela que estes surgem em zonas de solos férteis e próximo das vias, posicionamento coincidente com a distribuição das villae. A segura identificação de algumas dessas manchas de vestígios com explorações agrícolas e, sobretudo, a avaliação da sua dimensão ou cronologia é, porém, extremamente complexa. A relação de proximidade de algumas villae com estas manchas de materiais sugere, ainda assim, que estes possam constituir equipamentos associados ou subsidiários daquelas. Para além de pequenas explorações, que podem corresponder a equipamentos integrados nas villae, haveria, concerteza, unidades de exploração agrária de tipo familiar, de menores dimensões, habitualmente classificadas como casais ou quintas (Carvalho 2008b). 


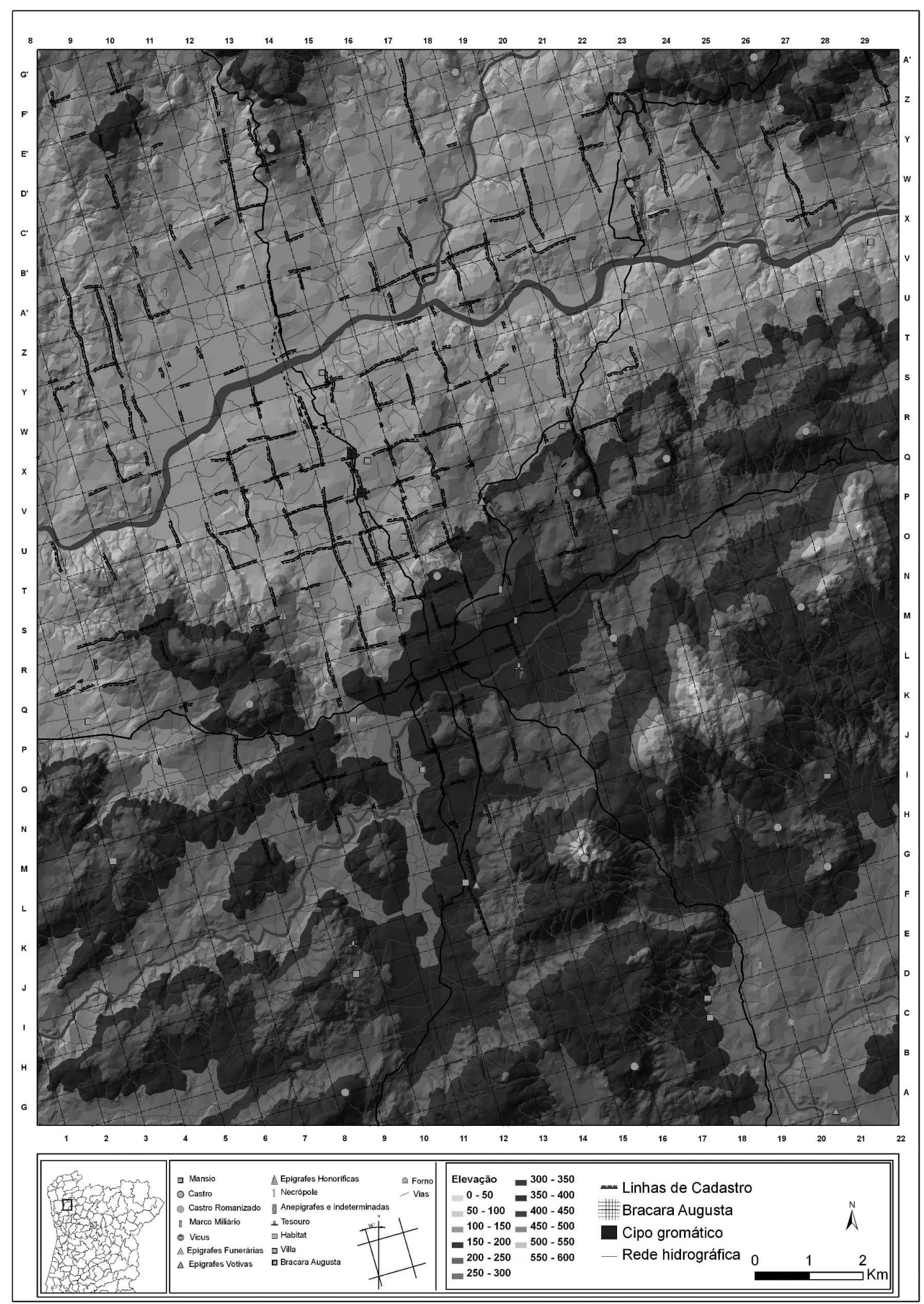

Figura 3. Traços recuperados e malha hipotética do cadastro romano. 


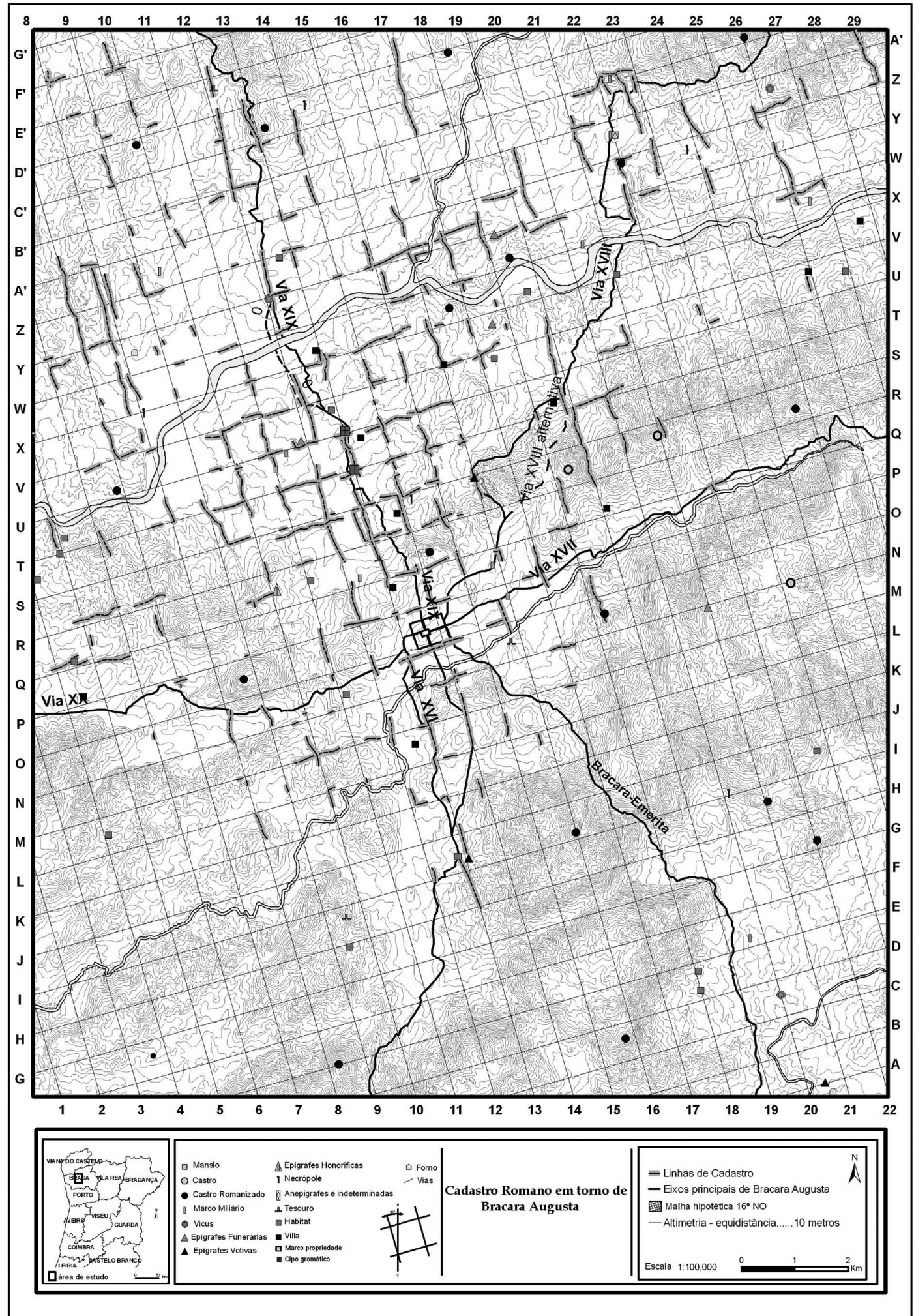

Figura 4. Malha do cadastro romano e vestígios arqueológicos em torno de Bracara Augusta. 
Aparentemente o rio Cávado, que atravessa esta zona, não representa um limite, no que respeita a alterações significativas do povoamento. A área a norte possui um conjunto denso de vestígios que se podem explicar quer pela ocupação das terras agrícolas situadas junto ao rio quer com a exploração de barreiros.

A área "industrial" mais significativa reconhecida no território em apreço é, sem dúvida, a que se situa entre Prado/Cabanelas e Ucha, que funcionou como centro abastecedor de argilas para as olarias de Bracara Augusta, o que poderá ter dado origem ao desenvolvimento neste local de um vicus (Martins 1990; Carvalho 2008b). A zona de barreiros de Cabanelas foi também, quase seguramente, um centro oleiro, onde para além de alguma cerâmica de mesa pode ter sido produzido o material laterício, indispensável à construção dos edifícios da cidade (Morais 2005). A presença de um centro, simultaneamente abastecedor de barros e produtor de cerâmicas, situado a cerca de $7 / 8 \mathrm{~km}$ de Braga, assume particular importância no contexto das relações económicas da cidade com a região envolvente. No entanto, a dimensão e a importância do sítio de Prado/Cabanelas como centro produtivo só poderão ser entendidas com uma investigação aprofundada, que implicará prospecções e escavações, no sentido de esclarecer as reais características do local e as suas relações com a cidade.

\section{O CADASTRO ROMANO E A ORGANIZA- ÇÃO DO ESPAÇO RURAL}

A investigação arqueológica sobre a morfologia do território tem ganho, nas últimas décadas, um papel cada vez mais importante na investigação arqueológica, tendência que reflecte, directa ou indirectamente, a aceleração dos ritmos e formas de intervenção nas paisagens contemporâneas.

As questões que se colocam quer teóricas quer metodológicas ao estudo dos parcelamentos rurais têm suscitado um amplo debate que radica, em última análise, nas diferentes perspectivas e abordagens da paisagem como objecto histórico e arqueológico. Ultrapassando uma perspectiva tradicional fortemente centrada no levantamento dos cadastros romanos e na sua relação, por vezes forçada, com o habitat rural e a malha urbana, procura-se fazer evoluir a investigação para uma história e arqueologia da paisagem. ${ }^{2}$

\footnotetext{
${ }^{2}$ Para uma síntese, necessariamente incompleta, desta problemática, poderão ver-se os seguintes trabalhos: Chouquer e Favory 1992; Clavel-Levêque e Vignot 1994; Clavel-Levêque e Orejas 2002; Ariño Gil et alii 1994 e 2004; Chouquer (dir.)
}

Os passos desenvolvidos no estudo do cadastro romano que apresentaremos de seguida correspondem, assim, a uma etapa de trabalho que exige uma longa agenda de investigação. Importa salientar, a este propósito, que o nosso interesse é fundamentalmente o de integrar o estudo do parcelamento rural da região num programa mais amplo de compreensão das dinâmicas de desenvolvimento deste território (Leveau 1997, 2000, 2005; Carvalho 2008b; Trément e Carvalho no prelo).

\subsection{Metodologia}

Partiu-se de uma área de estudo com cerca de 19,5 $\mathrm{km} \mathrm{N} / \mathrm{S}$, por $23 \mathrm{~km}$ Este/Oeste em torno da cidade, o que corresponde, sensivelmente, ao espaço abrangido pelas Cartas Militares de Portugal à escala 1:25000, folhas 56 e 70 (Figs. 3 e 4). A escolha desta área deveu-se a dois factores: esta é, antes de mais, a região que, grosso modo, pode considerar-se a área rural de influência directa da cidade; por outro lado, pode estimar-se como uma área suficientemente sugestiva, quer em termos de extensão, quer de condicionantes geomorfológicas para o objectivo pretendido (Carvalho e Bernardes 2000; Carvalho 2000; Carvalho 2008a).

A metodologia utilizada pode sintetizar-se em três operações fundamentais: trabalhos de carto e fotointerpretação, prospecções arqueológicas e pesquisa de fontes documentais.

As coberturas aéreas utilizadas de forma sistemática foram a de 1938 da SPLA à escala 1:18000 e as de 1947 da RAF na escala 1:30000. ${ }^{3}$ Ao trabalho de

1996 e 1997; 2003; Palet i Martinez 1994; Franceschelli e Marabini 2007; Dall'Aglio 2004; Compatangelo-Soussignan 2008 ; Chouquer 2007. As crónicas regulares de Monique Clavel-Levêque na revista Dialogues d'Histoire Ancienne permitem acompanhar o enriquecimento e o aumento da complexidade teórica e prática do estudo dos cadastros. A base de dados Atlas Historique des Cadastres et des Mines d'Europe constitui um acervo crescente de informação, consultável no site do Institut des Sciences et des Techniques de l'Antiquité, em http://ista.univ/fcomte.fr/bdd_images/index.php. Mais recentemente, a revista Agri centuriati: an International Journal of Landscape Archaeology passou a constituir uma fonte importante de actualização sobre a matéria. Finalmente, é indispensável a consulta dos trabalhos de arqueogeografia acessíveis através do site http://www.archeogeographie.org/ index.php?rub=presentation/archeo.

${ }^{3}$ A primeira cobertura aérea foi elaborada pela empresa denominada Serviço Português de Levantamentos Aéreos (SPLA), cujo espólio foi adquirido pelos Serviços Cartográficos do Exército (SCE). A única informação que foi disponibilizada aos SCE foi a de que esta cobertura aérea terá sido efectuada entre 1938 e 1948. A observação sectorial de alguns eixos conservados da cidade romana permite-nos verificar que estes fotogramas são anteriores ao levantamento aé- 
foto-interpretação juntámos a análise da cartografia 1:25000 e os levantamentos do território à escala 1:5.000, de 1968. O trabalho foi realizado num Sistema de Informação Geográfica elaborado para o efeito. ${ }^{4} \mathrm{O}$ recurso à fotografia de satélite para os trabalhos básicos de reconhecimento da rede viária e da estrutura geral do parcelamento foi também efectuado.

Os trabalhos de prospecção permitiram o controle dos dados sugeridos pela foto-interpretação. Numa primeira fase, os trabalhos concentraram-se na região a norte de Braga, num transepto onde se insere o traçado da via XIX, no seu percurso entre Braga e o rio Cávado. ${ }^{5}$ A opção obedeceu a uma série de condições, entre as quais destacamos: as características topográficas e geomorfológicas desta área, que a tornam passível de uma prospecção intensiva; a grande densidade de vestígios romanos já conhecidos, em que se destaca a zona arqueológica da villa de Dume (Fontes 1990; 1991-92; 2006); a necessidade de averiguar, com detalhe, nesta área, o traçado da via XIX; o facto da região ser uma excelente zona de ensaio para pesquisas relativas à transformação da paisagem desde a época romana até à Idade Moderna, devido à documentação disponível.

Para além deste transepto, outras áreas foram prospectadas, seguindo outras metodologias, consoante as condições efectivas do terreno e os diferentes objectivos, entretanto delineados. Em algumas zonas aplicámos uma metodologia de prospecção intensiva, com recolha, registo e identificação dos materiais recolhidos. Noutros casos, as prospecções incidiram na identificação, fotografia e registo de informações relativas a alguns traços de parcelamento, registando o seu uso actual, estado de conservação, características de delimitação dos eixos e formas de cultivo ou uso dos solos confinantes.

\subsection{ReCONSTitUiÇÃo DA MALHA CENTURIADA}

A procura de eixos ortogonais que possam indicar uma centuriação implica um conjunto complexo

reo feito em 1947 pela Royal Air Force (RAF), mas a imprecisão subsiste pelo que deve ter-se presente que quando nos referimos à cobertura de 1938 para a região em causa estamos a falar de uma data provavelmente posterior mas, de qualquer forma, anterior a 1947.

${ }^{4}$ A plataforma SIG foi inicialmente executada em Map GrafixPPC 3.5, associada a uma base alfanumérica em 4thDimension, e posteriormente migrada para ARQGIS 9.2. $\mathrm{Cf}$. Bernardes e Carvalho 1996; Carvalho 2008b.

${ }^{5} \mathrm{Na}$ apresentação do trabalho optámos por legendar a grelha hipotética do cadastro com um sistema de números para os eixos N/S e letras para os que se dispõem no sentido E/O. O transepto referido define-se, grosso modo, pela intersecção dos eixos 12,13 e 14 com os Q a W. (Ver Fig. 3). de procedimentos. Antes de mais, importa distinguir os grandes eixos estruturadores do parcelamento dos pequenos eixos ortogonais que podem não indicar mais do que uma simples ortogonalidade (Leveau 2000; Favory 1997; Ariño Gil et alii 2004).

Entre estes eixos estruturadores, importa antes de mais referir a rede viária representada pelos principais itinerários fundados na época de Augusto: as vias XVI, XVII e XIX. Implantadas em corredores de circulação naturais, estas vias romanas de primeira ordem parecem ter condicionado a organização estrutural do parcelamento A esta rede principal, convém acrescentar a via secundária que seguia para Oeste, ligando Bracara Augusta à região de vale, ao mar e a um possível porto fluvial no rio Cávado (Fig. 4). Este conjunto de quatro vias romanas coincide, em parte dos seus traçados, com a malha da centuriação proposta e configura-se como uma rede estruturante da organização do espaço rural em torno da cidade.

Alguns outros eixos viários de cronologia mais recente constituem parte integrante e coerente deste conjunto de alinhamentos, nomeadamente parte da actual estrada entre Braga e o rio Cávado, e estradas secundárias que podem ter fossilizado antigos eixos romanos.

Para além destes, foi possível identificar em trabalhos de prospecção caminhos pedonais, ladeados por muros ou cercas, que delimitam actualmente propriedades rurais ou servem de caminhos de circulação entre os campos.

Passemos à análise mais detalhada dos eixos identificados. Os cardos melhor conservados correspondem a eixos que atravessam todo o território analisado, ultrapassando o rio Cávado.

Um dos cardos cuja nitidez e persistência são mais significativas é aquele que constitui o limite oeste da cidade, estando presente em toda a área a norte da mesma, coincidindo em alguns pontos com o traçado da via XIX (13 S, T, U), prolongando-se a sul da cidade, num eixo que segue parte do traçado da via XVI (13 J a O).

Um outro importante alinhamento corresponde ao cardo 12 que se estende desde a área de Cones, a oeste da cidade, por Real, coincidindo parcialmente com o trajecto da actual estrada Braga/Prado.

Os eixos correspondentes a decumani são mais dificilmente detectáveis.

A sul da cidade, encontra-se bem conservado o decumanus correspondente ao eixo $\mathrm{O} 13,14$ e 15, visível na cartografia e fotografia aérea.

A pesquisa de orientações foi realizada, numa primeira fase, num leque entre $15^{\circ}$ e $20^{\circ} \mathrm{NNO}$, tendo em linha de conta a malha ortogonal de Bracara 
Augusta cuja orientação é relativamente homogénea em toda a cidade, sendo $19^{\circ} \mathrm{NNO}$ o ângulo da orientação de vários quarteirões e construções identificados (Martins et alii 2012).

Foi igualmente realizada a pesquisa de equidistâncias regulares em actus, particularmente as de 2 actus (=240 pés quadrados de 70,96m de lado) e de 5 actus (quadrados de 177,4 m de lado), com resultados particularmente interessantes no parcelamento a norte da cidade romana (Carvalho 2008b).

Recuperámos, assim, uma malha de um cadastro que se orienta a $16^{\circ} \mathrm{NNO}$ com uma orientação e modulação regular em actus, particularmente visível nos alinhamentos conservados entre os eixos 7 a 19 e M a Y. Este cadastro ter-se-á organizado em centúrias de 20 × 20 actus, o que configura centúrias de 200 iugera de superfície.

A malha proposta de 20 × 20 actus encontra-se corroborada pela intersecção nítida de alguns eixos, particularmente clara nos eixos 11 a 5 com os $\mathrm{V}, \mathrm{U}$, T, S, R ou, a norte do Cávado, o Y com 7, 8, 15,16 e 17. A sul da cidade o cruzamento dos eixos $\mathrm{O}$ com 13, bem como o P com os 12, 13 e 14, ajuda a confirmar esta modulação (Fig. 3). O achado de elementos delimitadores do cadastro, de que trataremos em seguida, permitiu-nos confirmar quer a orientação quer o módulo sugeridos.

Os traços recuperados possuem uma orientação $\mathrm{NO} / \mathrm{SE}$, perfeitamente adaptada às formas estruturantes do relevo e à rede hidrográfica principal e encontram-se na área entre 5 a $7 \mathrm{~km}$ em torno da cidade.

A sobreposição dos layers correspondentes à altimetria e hidrografia (escala 1:25000) permite verificar que o parcelamento recuperado ocupa as zonas de vale, em cotas que se situam, preferencialmente, entre os 10 e os 60 metros de altitude, nunca ultrapassando a curva de nível dos 200 metros.

A zona centuriada parece corresponder, assim, a uma vasta área que configura um amplo rectângulo, que abrange um território de altitudes menos elevadas e solos com um considerável potencial agrícola, cortados pelas vias romanas que saiam de Braga. Os limites estão definidos pelas elevações de altitudes que variam entre os 250 e os 350 metros, com excepção das maiores elevações representadas pelo castro de S. Mamede/Guizande, com 427 metros, e o monte de Santa Marta da Falperra, com 562 metros, ambas na zona sul da área estudada.

A centuriação prolonga-se ainda numa área de baixas altitudes na margem direita do rio Cávado, sendo particularmente visível na veiga de Cabanelas, a noroeste e, também, na região que abrange a con- fluência dos rios Cávado e Homem, em cerca de 4 $\mathrm{km}$ para norte, tomando o rio Cávado como referência. Aí os limites da zona correspondem aos terrenos de maior elevação visíveis na topografia, correspondentes a altitudes que oscilam entre os 120 e os 174 metros de altitude (Figs. 3 e 4).

O carácter sistemático desta orientação, a modulação em actus e a sua articulação, quer com o traçado da cidade, quer com o dos principais eixos viários da região abertos na época de Augusto (vias XVI, XVII e XIX) permitem sugerir uma centuriação provavelmente ligada à fundação de Bracara Augusta e à projecção da rede viária na época júliocláudia, tal como acontece, por exemplo, em Barcino onde a centuriação poderá estar vinculada à fundação da cidade na época de Augusto (Palet i Martínez 1994: 111).

\subsection{TERMINI ANTIQUI}

A modulação e a orientação deste parcelamento centuriado encontram-se confirmadas pela presença física de limites ou termini. As operações de delimitação podiam materializar-se em limites físicos com diversas morfologias: cipos simples sem inscrição, cipos com inscrições mais ou menos detalhadas, mas também pequenos templos ou edículas. Havia ainda a possibilidade de proceder a delimitações através da disposição dos caminhos e de árvores, entre outros elementos. Alguma da literatura latina que chegou até nós especifica e cataloga estes elementos físicos de demarcação de limites (Chouquer e Favory 1992: 1826; Favory et alii 1995; 1996; 1997).

Os cipos gromáticos podem ter mais do que uma função, servindo para delimitar lotes atribuídos a colonos, marcar limites entre territórios de cidades ou assinalar eixos de uma delimitação e respectivos caminhos. Alguns destes cipos apresentam na parte superior o entalhe de uma cruz, o decussis, representando os dois limites a definir, o Kardo e o Decumanus, que se cruzam no lugar onde está implantado o cipo e indicam a respectiva orientação desses dois eixos (Chouquer e Favory 1992 ; Favory et alii 1995, 1996, 1997; VVAA 1989: 99, 136-144, 196-198; Decramer et alii 2002).

Os trabalhos de prospecção que realizámos em 2004 permitiram-nos identificar dois cipos gromáticos (doravante designados como cipo 1 e cipo 2). Ambos foram talhados em blocos de granito e apresentam a face superior perfeitamente alisada, onde se gravou uma cruz que a ocupa completamente. Estes dois cipos encontram-se num dos eixos melhor con- 
servados da malha recuperada e distam entre si, precisamente, uma centúria (20 actus) (Fig. 11).

O cipo 1 situa-se no lugar conhecido como Felgueira e serve de limite entre as freguesias de S. Martinho de Dume e S. Pedro de Merelim. Trata-se de um monumento de 0,46 metros de altura máxima visível (na observação feita em 2004), 0,38 metros de largura, faces almofadadas, topo plano e alisado com duas linhas cruzadas (Fig. 5).

A intervenção arqueológica que realizamos em 2006 pretendia determinar a dimensão e características do monumento, o seu sistema de implantação no terreno (existência ou não de base ou soco) e, se possível, a sua cronologia de implantação.

Foi para o efeito implantada uma sondagem de $2 \times 1 \mathrm{~m}$, cujo limite oeste foi marcado sensivelmente a meio do cipo, de forma a obter uma leitura estratigráfica conveniente (Figs. 6 e 7).

A escavação efectuada revelou um monumento de $1 \mathrm{~m}$ de altura por $40 / 50 \mathrm{~cm}$ de largura máximas, sem vestígios de soco, tendo-se confirmado a existência de vestígios de almofadado em 3 faces. A inexistência de vestígios materiais, cerâmicos ou outros, durante a escavação, não permite uma comprovação estratigráfica da sua antiguidade nem dos eventuais remeximentos e deslocações a que o monumento poderá ter sido sujeito durante um grande lapso de tempo. No entanto, a semelhança com alguns cipos

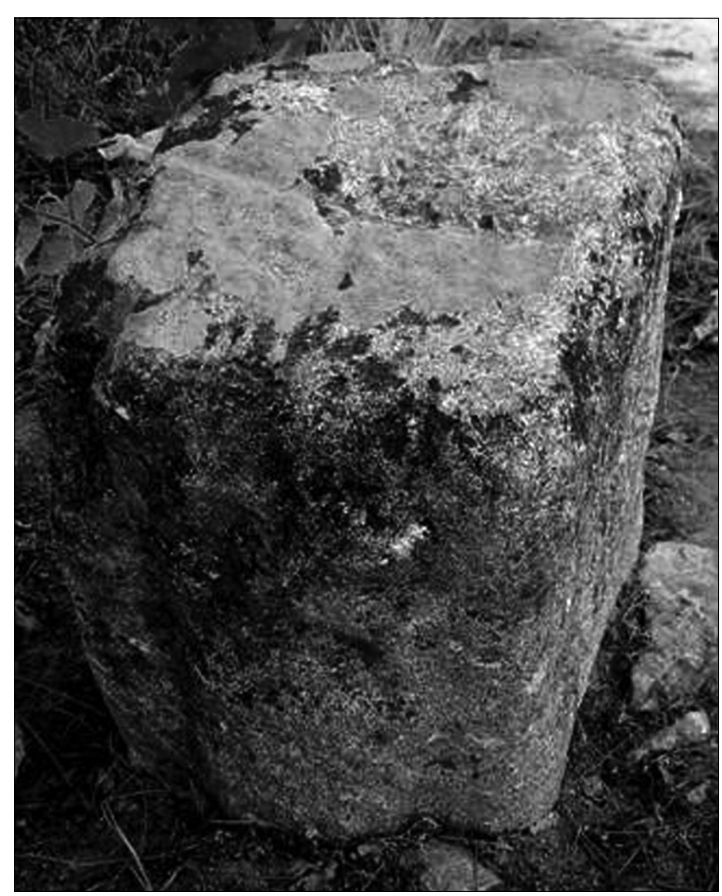

Figura 5. Perspectiva do Cipo 1-(fotografia de 2004).

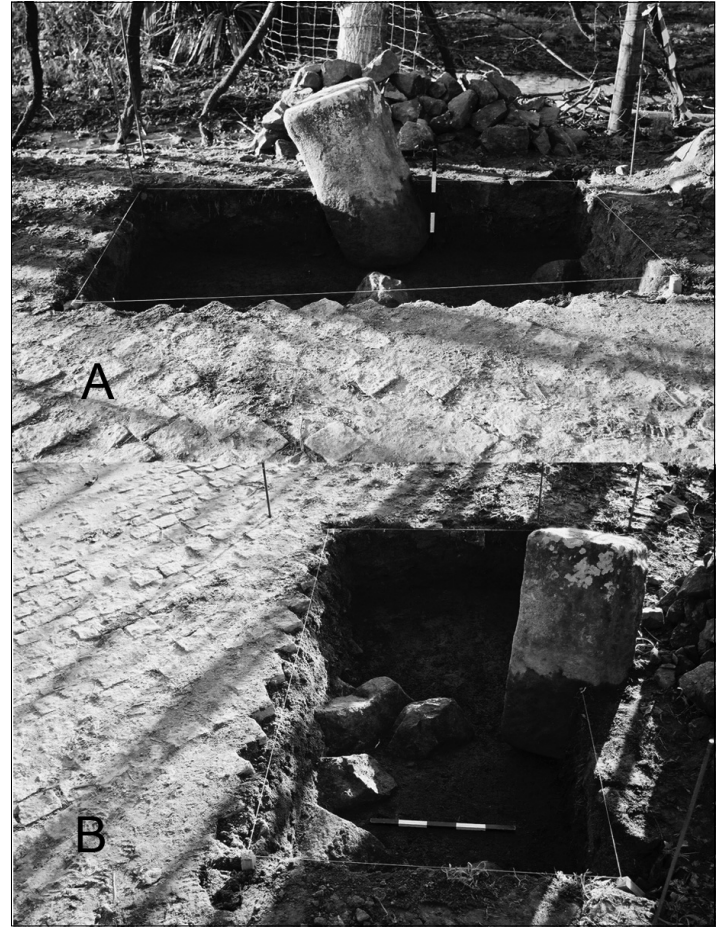

Figuras 6. A e B. Perspectivas da sondagem do Cipo 1(fotografias de 2006).

encontrados noutras áreas do mundo romano e a comparação com imagens e descrições patentes em obras de agrimensura latina não nos deixam dúvidas quanto ao facto de estarmos perante um exemplar raro e extremamente bem conservado de um cipo gromático, a que não falta, inclusivé, o alinhamento dos eixos da centuriação dado pelo cruzamento das duas linhas no topo ou decussis.

$\mathrm{O}$ achado de um segundo monumento, com as mesmas características tipológicas, a cerca de 20 actus de distância, confirma, aliás, esta ideia. O cipo 2 situa-se em Pinhel e limita três freguesias: S. Pedro de Merelim, S. Martinho de Dume e Palmeira. Trata-se, tal como o anterior, de um monumento talhado em granito e possui $47 \mathrm{~cm}$ de altura máxima e $28 \mathrm{~cm}$ de largura máxima (medidas visíveis). Embora em pior estado de conservação que o anterior, possui igualmente o topo alisado e duas linhas gravadas em cruz ou decussis (Fig. 8).

A explicação para a manutenção destes dois monumentos resulta da sua constante utilização como elementos demarcatórios. De limites de um eixo romano a instrumentos delimitadores do espaço paroquial de Dume, até marcos divisórios entre freguesias, a sua presença mantém-se numa "imobilidade" espantosa, "imobilidade" mantida e rigorosamente 


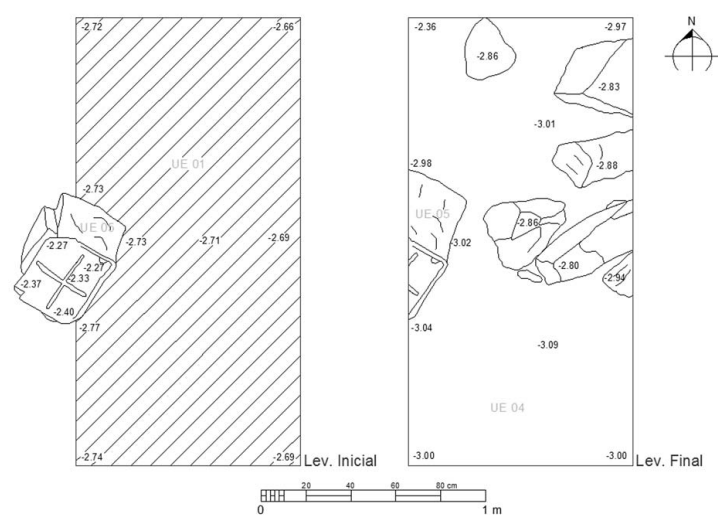

Figura 7. Sondagem do Cipo 1-levantamento inicial e final.

preservada, ainda hoje, quer pelos proprietários das terras quer pelas autoridades públicas. ${ }^{6}$

A leste destes cipos localiza-se um outro marcador. No lugar conhecido como Fonte de S. Vicente, no sopé da vertente oeste de Montariol, existe uma nascente de água que brota da rocha, onde foi talhado um tanque quadrado, semelhante a um tipo de representações de limites que ocorre nos tratados de agrimensura romanos e medievais, e designado de archa petrinea (Figs. 9 e 11) (Chouquer e Favory 1992; Favory 2003; Portet 2004). Junto ao local, encontrou-se tijolo e tegulae (Fontes 1994), e de um dos muros junto à fonte foi retirada uma ara votiva dedicada a Marte Tarbucelis, pelos membros da família dos Coporicius Maternus, pisoeiros: COPORICI/ MATERNI/ EX VOTO/ MARTI TAR/BVCELI FV[L]LONES (Fig. 10) (Santos et alii 1983: 183-205). A presença de uma

\footnotetext{
${ }^{6} \mathrm{O}$ litígio sobre os limites paroquiais de Palmeira, ocorrido em meados do século xviII, comprova o que acabámos de dizer. Nos documentos utilizados pelo Tribunal da Relação Eclesiástica de Braga na definição dos limites de Palmeira consta a transcrição de um tombo particular de propriedades que mediu e confrontou algumas linhas de divisão em que, aparentemente, cipos gromáticos do tipo dos acima descritos parecem manter uma função demarcatória: "na estrada do caminho travesso que vai da estrada publica para felgueiras [...] continuando a dita demarcaçam pello dito caminho de poente a nascente athe o fim da quingosta que vai para o Monte de felgueiras e dahi curtando direito por dentro da bouça [...] athe hum marco que fica [...] no monte devizam da freguesia de Sam Pedro frossos e Sam Martinho de Dume e deste marco continuando a demarcaçam da freguesia de Sam Martinho com a de Sam Pedro pello monte de felgueiras asima para a parte do monte athe o heido [...] aonde está hum marco grande quazi enterrado que esta em hum pumar [...] e continuando a demarcaçam deste marco pera a parte do monte pello caminho de dentro onde estam tres marcos todos tres direitos huns e outros todos com suas cruzes por sima". Cf. Arquivo Distrital de Braga (ADB), Tribunal da Relação Eclesiástica de Braga, Sentença sobre os limites de Palmeira 1751-1771, pasta $11, \mathrm{n}^{\circ} 583$, fls. 78-78v. O tombo particular utilizado no processo litigioso é o da Comenda de S. Pedro de Merelim, datado do ano de 1735 .
}

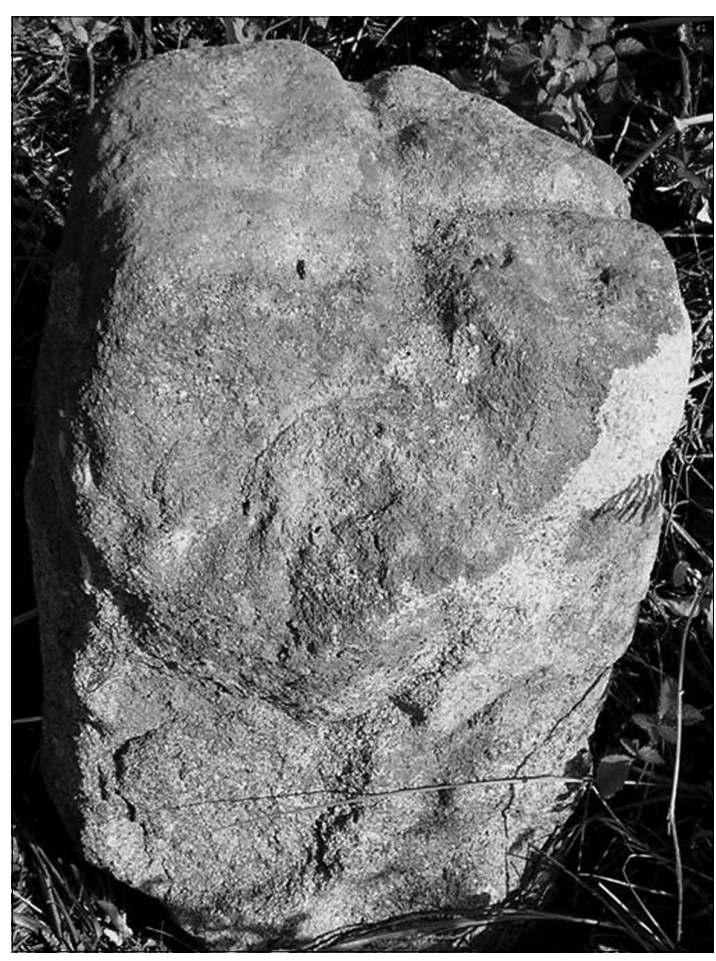

Figura 8. Perspectiva do Cipo 2 (fotografia de 2004).

archa petrinea, curiosamente associada a uma inscrição votiva a Marte, é de suma importância.

Neste sector, a transformação da villa romana de Dume, cuja fundação remonta a inícios do século I d.C., numa igreja monástica, sede de uma diocese entre os séculos VI-VII, deve ter arrastado consigo a cristalização de algumas marcas centuriadas na periferia imediata da cidade. Com feito, a configuração da diocese de Dume relativamente à diocese de Braga parece ter reutilizado a função demarcatória de antigos limites. O Liber Fidei, cartulário construído pelos bispos bracarenses, entre os séculos XII e XIII, para servir de prova do património da diocese face a Santiago de Compostela alinha, precisamente, os termos antigos das duas dioceses, deixando entrever a presença densa de elementos naturais e construídos de delimitação.

Num dos primeiros documentos aí copiados, datado de 911, a delimitação da antiga diocese de Dume por ordem do rei Ordonho II da Galiza, fixa não apenas os aglomerados que então eram designados como villae, como utiliza diversificada e sincopadamente elementos demarcatórios - archae, petras fictas, terrae tumeda -, aparecendo logo no início a referência ao monumento da fonte de S. Vicente, de Montariol: "Et tunc venimus nos iam supra dicti pre- 
visores ad ipsum locum, ascendimus in montem qui est inter ipsum locum et villa quem dicunt infidias, invenimus ibidem in petra caracterem Sancti Vincenti et exinde in alia petra invenimus cruce et inde per petras fictas qui ab antiquo pro termino fuerunt constitutas et exinde in via quam dicunt de Vereda qui discurret de Bracara et invenimus ibidem congesta magna petrinea et inde per agirem et petras fictas quousque in archa qui sedet sculta in petra et exinde ad alia congesta terrinea et inde per agirem et petras fictas qui sunt secus via de Vereda quousque in termino de Pittanes et inde per agirem et archas principias qui divident inter Dumio et Palmaria et exinde per agirem Certuor qui dividet inter Dumio et Paretelias et inde per totum ipsum agirem usque in termino de Lesmiri et inde per alia via de Vereda qui discurrit de Bracara quousque inter tumeda qui fuit manum facta et exinde in archa petrinea principia $a b$ antiquis constructa qui dividet inter Dumio et villa Lesmiri et inde per agirem firmissimum qui dividet inter Dumio et villa de Forozos usque ad alia archa petrinea qui dividet inter Dumio et Parata Samueli et Forozos et sic per agirem et per petras fictas usque ad congesta qui dividet inter Dumio et Culina et inde per agirem et per petras fictas usque in termino de villa Pascasi et invenimus ibidem petra scripta ubi dicet Sancte Eolalie ubi dividet Dumio, Culina et villa Paschasi et sic eximus per signas certas usque in montem ubi prius incoavimus et invenimus in ea ipsos terminos parietes quos obtinuit Spasandus et alias quos obtinuit Alamirus seu et ecclesia vocabulo Sancti Fructuosi quod dicunt Montelios. Et quod potuimus previdere in veritate sunt ipsi termini fortissimi ab antiquis constructi ipsius loci iam fati et manibus nostri confirmamus" (Costa 1965: 39-40).

Se aceitarmos que a paróquia de Dume herda o espaço da antiga diocese, assente por sua vez numa antiga villa romana, não deixa de ser elucidativa a descrição que dela se faz no inquérito paroquial promovido pela Coroa portuguesa em 1758, após o Terramoto de Lisboa: "Fora dos suburbios da muito antiga, nobre e leal cidade de Braga, Primaz das Hespanhas, para a parte do Norte, em a espaçosa ribeira que cruza o Cavado com o dillatado giro de seu curso, se extende aprazivelmente agradavel, a freguesia de Sam Martinho de Dume, em outro tempo celebre Bispado. Está situada esta freguesia quazi em figura quadrangular; supposto que da parte que corre do meio dia a Poente e de Nascente a Norte, se lhe perceba mais alguma extenção, não hé couza que a deforme da sua quadrangular figura" (Capela 2003: 172-174). A figura de um quadrado, ancorada agora no parcelamento centuriado aqui em análise, de certo modo fossiliza a persistência dos marcadores antigos (Fontes et alii 2010).

Aparecendo referida na documentação medieval como elemento de delimitação do termo da antiga diocese de Dume, é provável, como referimos, que a archa petrinea tivesse já servido como marcador do cadastro romano. Neste contexto, o alinhamento da archa com os dois cipos gromáticos, no âmbito da reconstituição do cadastro romano, é fundamental (Fig. 9).

A localização e distância entre os dois cipos permite a confirmação de um módulo de 20 actus, pelo menos na orientação dos cardos. A localização da archa petrinea pode corresponder a uma intersecção dos eixos $\mathrm{S}$ e 16 que coincide com a malha teórica do cadastro e poderia marcar o limite da área centuriada nesta zona, dada a elevação de Montariol que ficou, provavelmente, fora desta assignatio. Esta archa petrinea representa um possível "travejamento" do cardo 16 , de orientação N/S com o decumanus $\mathrm{S}$ o que confirma a orientação de $16^{\circ} \mathrm{NNO}$ e, conjugada com a localização dos dois cipos, a modulação de 20 actus.

Importa, por último, considerar a persistência eventual de fossos antigos cujas funções de limite se mantêm até serem desactivados por alterações no parcelamento. Esse levantamento, antes de mais arqueológico, convida mais uma vez, ao cruzamento e ponderação de vários indícios documentais que, de forma regressiva, mostram a incidência de determinados marcadores. $\mathrm{O}$ eixo do cadastro romano recuperado e identificado como P12 a P15 poderá, nestas circunstâncias, corresponder ao traçado de um "valo velho", descrito no século xv, nos arrabaldes da cidade, no alinhamento de S. Vicente, demarcando uma propriedade que intercepta as saídas para S. Martinho de Dume e Palmeira: "Item acçima dos Chaaos honde descobre o cano estam bõns vij carvalhos todos juntos E tem no pee uma mea + por esta guissa. Item logo abaixo quando vam para Sam Viçente, junto da porta principall do dito Sam Vicente a maão ezquerda estão vij carvalhos bõns com a dita marca dos outros de cima.Item logo abaixo de Sam Vicente esta hua leira de devessa a mayor parte dela nova que tem cem carvalhos daqueles antre grandes e pequenos $E$ a dita leira partida ou demarcada per huum vallo velho .s. que de contra o soaão E de contra o poente parte pella estrada que vay da cidade pera Sam Martinho de Dume $E$ a dita leira atravessa todas as estradas.s. a que vay para Sam Martinho e a que vay pera Palmeira". ${ }^{7}$

${ }^{7}$ ADB, Cabido, Tombo 4 ${ }^{\circ}, 1493-1512$, fls. 51v-52. O traçado deste valo velho aparece documentado noutros registos, 


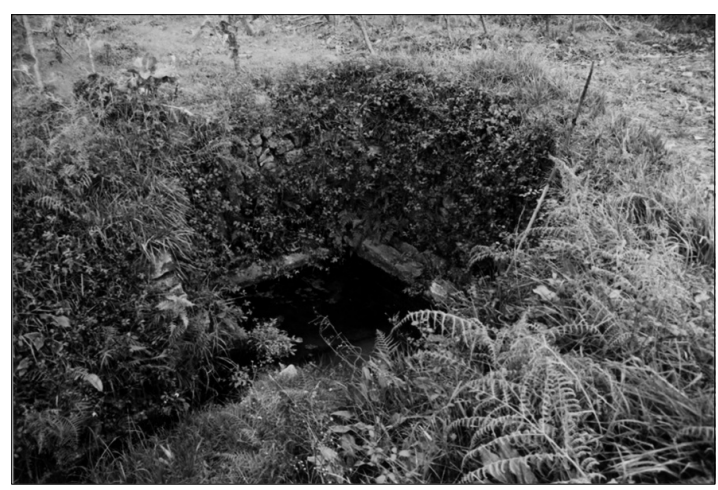

Figura 9. Archa petrinea.

\section{PERSPECTIVAS FINAIS}

As formas paisagísticas humanizadas não só não evoluem linearmente, como mantêm entre si graus elevados e complexos de coexistência temporal. A presença de marcas na paisagem, quer sejam cipos ou antigos caminhos que preservaram limites do cadastro romano - visíveis na cartografia e detectados em prospecções - , pode relacionar-se com mecanismos de permanência, reutilização e reciclagem que se socorreram da malha de centúrias estabelecida em época romana, sendo sucessivamente "activados" ou "desactivados".

Estas questões exigem escalas de análise, quer

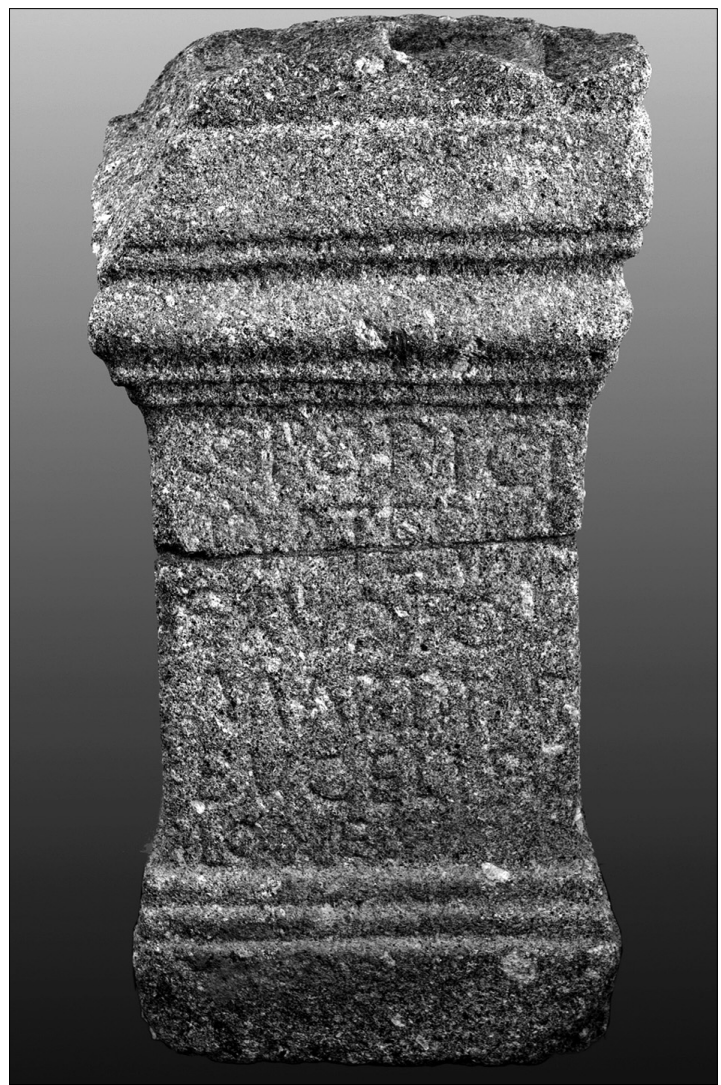

Figura 10. Ara dedicada a Marte (Depósito e fotografia: Museu Pio XII).

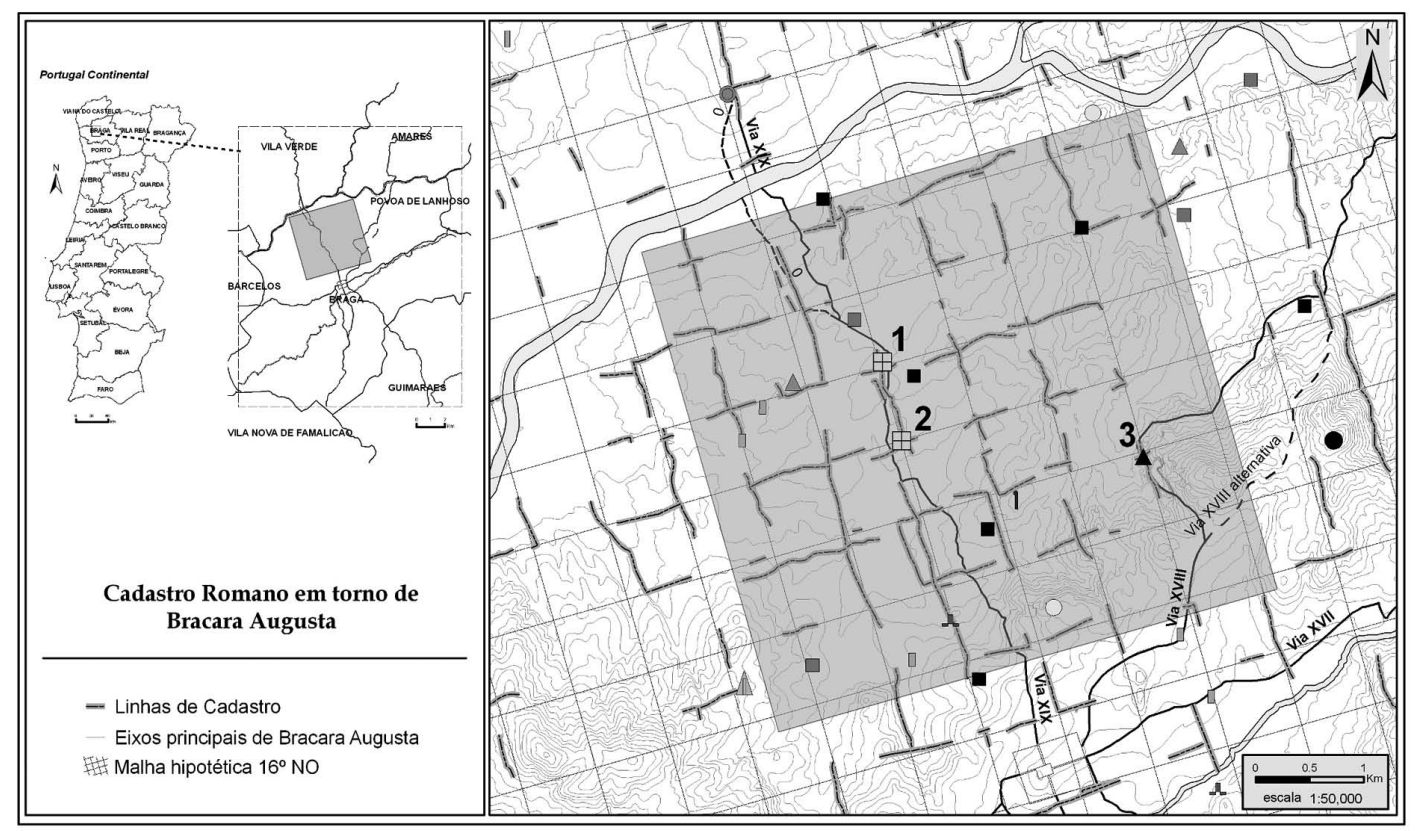

Figura 11. Localização dos cipos e da fonte identificada como archa petrinea- 1, 2 e 3. 
temporais quer espaciais, em que os dados possam ganhar um maior grau de inteligibilidade. $\mathrm{O}$ encadeamento de indícios relativos à intervenção cadastral no território próximo da cidade implicará, no futuro, intensificar a articulação dos trabalhos arqueológicos com a análise dos arquivos que documentam a posse da terra. O programa de trabalho em torno do parcelamento rural de Braga, ensaiando um inventário da reconstituição das formas, visíveis ou fossilizadas na paisagem, exige, assim, articular e desbloquear a massa documental conservada. Estas tarefas possibilitarão detectar incidentes topográficos, alinhamentos, referências a valos velhos, limites, caminhos, o que desencadeia um estudo fundamental na abordagem da permanência, transformação e reciclagem de traços e formas. No âmbito da definição de escalas pertinentes parece-nos que só o desdobramento de áreas de análise e uma inevitável pesquisa na longa duração, sobre documentação diversificada, assegurarão com eficácia os estudos relativos à arqueologia desta paisagem (Carvalho e Mendes 2010; Martins e Carvalho 2010; Carvalho e Ribeiro no prelo).

\section{BIBLIOGRAFIA}

Argote, J. C. 1732-34: Memórias para a História Eclesiástica do Arcebispado de Braga, Primaz das Hespanhas, Lisboa, 4 vols.

Ariño Gil, E., Gurt Esparraguerra, J. M., Lanuza Garriga, A. E e Palet i Martínez, J. M. 1994: “El estudio de los catastros rurales: una interpretación estratigráfica del paisaje", Zephyrvs 57, 189-217.

Ariño Gil, E., Gurt Esparraguerra, J. M. e Palet Martínez, J. M. 2004: El pasado presente. Arqueología de los paisajes en la Hispania romana, Acta Salmanticensia. Estudios históricos \& geográficos 122, Barcelona.

Bernardes, J. e Carvalho, H. 1996: "Aplicação de um S.I.G. à arqueologia romana dos territórios de Bracara Augusta e Collippo", Actas do II Congreso Peninsular de Arqueologia, Zamora.

Braga, C. 2010: Rituais Funerários em Bracara Augusta: o novo núcleo de necrópole da Via XVII, Tese de mestrado, Braga. http://hdl.handle.net/ $1822 / 13913$

Capela, J. 2003: As freguesias do Distrito de Braga nas Memórias Paroquiais de 1758. A construção do imaginário minhoto setecentista, Braga.

inclusive numa representação cartográfica de Braga de meados do século XVIII (Carvalho 2008b). Interessará, no futuro, estudar a articulação destes valos com o sistema de drenagem e irrigação, de forma a medir o seu papel na evolução do parcelamento (Carvalho e Ribeiro no prelo).
Carvalho, H. 2000: "Parcelamento rural de Bracara Augusta: questões metodológicas", Actas do $3^{\circ}$ Congresso Peninsular de Arqueologia. VI. Arqueologia da Antiguidade na Península Ibérica, Porto, $143-146$.

Carvalho, H. 2008a: "Organisation cadastrale autour de Bracara Augusta, Braga (Portugal)", Dialogues d'Histoire Ancienne 34/1, 155-160.

Carvalho, H. 2008b: O povoamento romano na fachada ocidental do Conventus Bracarensis. Tese de doutoramento, Braga, 3 vols. http://hdl.handle.net/ $1822 / 8755$.

Carvalho, H. e Bernardes, J. 2000: “O povoamento romano de Bracara Augusta e Collippo: exemplos de aplicação de um S.I.G.", Actas do $3^{\circ}$ Congresso Peninsular de Arqueologia. X. Sistemas de Informação Arqueológica-SIG's aplicados à Arqueologia da Península Ibérica, Porto, 125-131.

Carvalho, H. e Mendes, F. 2010: "Centuriazione e evoluzione degli assetti agrari intorno alla città di Bracara Augusta (Hispania Citerior Tarraconensis)", Agri Centuriati: an International Journal of Landscape Archaeology 7, 155-166.

Carvalho, H. e Ribeiro, M. C. (no prelo): “Aménagement et exploitation des espaces rural et urbain: Bracara Augusta et son territoire (un questionnaire préalable)", Aménagement et exploitation des zones humides depuis l'Antiquité. Approches comparées en Europe méditerranéenne et continentale, Clermont-Ferrand.

Chouquer, G. 1996: "Les formes du paysage. 2. Archéologie des parcellaires", Actes du Colloque d'Orléans, Paris.

Chouquer, G. 1997: "Les formes du paysage. 3. L'analyse des systèmes spatiaux", Actes du Colloque d'Orléans, Paris.

Chouquer, G. 2003: "Crise et recomposition des objets: les enjeux de 1'archéogéographie", Études Rurales 167-168, 13-32.

Chouquer, G. 2007: “Quels scénarios pour l'histoire du paysage?" Orientations de recherche pour l'archéogéographie, Coimbra-Porto.

Chouquer, G. e Favory, F. 1992: Les arpenteurs romains. Théorie et pratique, Paris.

Clavel-Lévêque, M. e Orejas, A. 2002: Atlas Historique des Cadastres d'Europe II, Brussels.

Clavel-Lévêque, M. e Vignot, A. 1998: Atlas Historique des Cadastres d'Europe, Luxeuil- les-Bains.

Compatangelo-Soussignan, R. 2008: "Introduction", J. Compatangelo-Soussignan, J. R. Bertrand, J. Chapman e P. Y. Laffont (eds.), Marqueurs des paysages et systèmes socio-économiques, Actes du Colloque COST du Mans, Rennes, 13-19. 
Costa, A. J. 1965: Liber Fidei Sanctae Bracarensis Ecclesiae, Braga.

Cruz, M. 2001: Vidros romanos de Bracara Augusta, Tese de mestrado, Braga.

Cruz, M. 2009: O vidro romano no Noroeste Peninsular. Um olhar a partir de Bracara Augusta, Tese de doutoramento, Braga, 3 vols. http://hdl.handle. net/1822/9883.

Cunha, R. 1634-35: História Eclesiástica do Arcebispado de Braga, Braga, 2 vols.

Dall'Aglio, P. L. 2004: "Perché studiare la centuriazione", Agri Centuriati: an International Journal of Landscape Archaeology 1, 17-22.

Decramer, L., Elhaj, R., Hilton, R. e Plas, A. 2002: "Approche géométrique des centuriations romaines. Les nouvelles bornes du Bled Segui", Histoire \& Mesure XVII - 1/2, http:// histoiremesure.revues.org/903

Delgado, M. e Lemos, F. S. 1985: "Zona das Carvalheiras. Notícia das campanhas de escavação de 1984 e 1985", Cadernos de Arqueologia (Série II) 2, 159-176.

Delgado, M. e Lemos, F. S. 1986: “Zona das Carvalheiras: notícia das campanhas de escavação de 1985", Cadernos de Arqueologia (Série II) 3, 151167.

Favory, F. 1997: "Retour critique sur les centuriations du Languedoc oriental, leur existence et leur datation", G. Chouquer (dir.), Les formes du paysage. 3. L'analyse des systèmes spatiaux, Paris, 96-126.

Favory, F., Gonzales, A., Guillaumin, J. Y. e Philippe, R. 1995: "Témoignages antiques sur le bornage dans le monde romain, II", Revue Archéologique du Centre de la France 34, 261-281.

Favory, F., Gonzales, A., Guillaumin, J. Y. e Philippe, R. 1996: "Témoignages antiques sur le bornage dans le monde romain, III", Revue Archéologique du Centre de la France 35, 203-216.

Favory, F., Gonzales, A., Guillaumin, J. Y. e Philippe, R. 1997: "Témoignages antiques sur le bornage dans le monde romain, IV", Revue Archéologique du Centre de la France 36, 203-209.

Ferreira, N., Dias, G. e Meireles, C. A. P. 2000: Carta geológica de Portugal (1/50.000). Notícia explicativa da Folha 5-D, Braga, Lisboa.

Fontes, L. 1990: "Escavações arqueológicas na antiga igreja de Dume", Actas do Congresso Internacional sobre o IX Centenário da dedicação da Sé de Braga, Braga, vol. I, 147- 169.

Fontes, L. 1991-92: "Salvamento Arqueológico de Dume (Braga). Resultados das Campanhas de 1989-90 e 1991-92", Cadernos de Arqueologia (Série II) 8-9, 199-230.
Fontes, L. 1993: "Inventário de Sítios Arqueológicos de Concelho de Braga", Mínia (3ª́rie) 1, 31-88.

Fontes, L. 2006: A Basílica Sueva de Dume e o Túmulo dito de São Martinho, Braga.

Fontes, L., Lemos. F. S. e Cruz, M. 1997-98: "Mais Velho` que a Sé de Braga. Intervenção arqueológica na catedral bracarense: notícia preliminar", Cadernos de Arqueologia (Série II) 14-15, $137-$ 164.

Fontes, L., Martins, M., Braga, C., Sendas, J. e Magalhães, F. 2008: "Escavações arqueológicas no Quarteirão dos Antigos CTT (Braga), Resultados Preliminares", Al- madan (Série II) 16, Almada, 5-9.

Fontes, L., Martins, M., Ribeiro, M. C. e Carvalho, H. 2010: "A cidade de Braga e o seu território nos séculos V-VII", Actas do Congresso Espacios Urbanos en el Occidente Mediterráneo, ss. VIVIII, Toledo, 255-262. http://hdl.handle.net/1822/ 13377

Franceschelli, C. e Marabini, S. (2007): "Lettura di un territorio sepolto. La pianura lughese in età romana", Studi e Scavi, Nuova Serie 17, Bologna.

Lemos, F. S. 2000: "A via romana entre Bracara Augusta e Asturica Augusta, por Aquae Flaviae (Contributo para o seu estudo)", Revista de Guimarães 110, 15-52.

Lemos, F. S. 2002: “Bracara Augusta - A grande plataforma viária do Noroeste Peninsular", Forum 31, 95-127.

Lemos, F. S. e Leite, J. M. F. 2000: "Trabalhos arqueológicos no logradouro da Casa Grande de Santo António das Travessas", Forum 27, 15-38.

Leveau, Ph. 1997: "Temps, espace et structuration des paysages", G. Chouquer (dir.), Les formes $d u$ paysage. 3. L'analyse des systèmes spatiaux, $\mathrm{Pa}-$ ris, 7-13.

Leveau, Ph. 2000: "L'archéologie des paysages aux époques historiques", Annales, Histoire, Sciences Sociales 3, 555-582.

Leveau, Ph. 2005: "L'archéologie du paysage et l'antiquite classique", Agri Centuriati: an International Journal of Landscape Archaeology 2, 9-24.

Mantas, V. G. 1996: A rede viária da Faixa Atlântica entre Lisboa e Braga, Tese de Doutoramento, Coimbra.

Mantas, V. G. 2000: "A via romana Bracara Augusta-Cale: traçado, funções e influência no povoamento regional", Revista de Guimarães 110, 5387.

Magalhães, F. 2010: Arquitectura doméstica em Bracara Augusta, Tese de mestrado, Braga. http:// hdl.handle.net/1822/13619. 
Martins, M. 1990: O povoamento proto-histórico e a romanização da bacia do curso médio do Cávado, Cadernos de Arqueologia, Monografias 5, Braga.

Martins, M. 1995: “A ocupação romana da região de Braga: balanço e perspectivas de investigação", Actas do Congresso Histórico Comemorativo dos 150 anos do Nascimento de Alberto Sampaio, Guimarães, 73-114.

Martins, M. 1997-1998: “A zona arqueológica das Carvalheiras. Balanço das escavações e interpretação do conjunto", Cadernos de Arqueologia (II série) 14-15, 23-45.

Martins, M. 1999: “A urbanização do Noroeste peninsular: o caso de Bracara Augusta", Actas da Mesa Redonda: Emergência e desenvolvimento das cidades romanas no Norte da Península Ibérica, Porto, 53-76.

Martins, M. 2000: Bracara Augusta cidade romana, Braga.

Martins, M. 2004: "Urbanismo e Arquitectura em Bracara Augusta. Balanço dos contributos da Arqueologia Urbana", Actas do Congresso Internacional 'Simulacra Romae. Roma i les Capitals provincials de l'Occident', Tarragona, 149175.

Martins, M. 2005: As termas romanas do Alto da Cividade. Um exemplo de arquitectura pública em Bracara Augusta, Bracara Augusta. Escavações Arqueológicas 1, Braga. http://hdl.handle.net/ $1822 / 13410$.

Martins, M. 2011: Braga romana, Braga.

Martins, M. e Carvalho, H. 2010: "Bracara Augusta and the changing of rural landscape", C. Corsi e F. Vermeulen (eds.), Changing landscapes. The impact of Roman Towns in the Western Mediterranean. Proceedings of the International Colloquium, Bologna, 281-298.

Martins, M. e Delgado, M. 1989-90: “As necrópoles de Bracara Augusta. Os dados arqueológicos", Cadernos de Arqueologia (Série II) 6-7, 41-186. http://hdl.handle.net/1822/10272

Martins, M. e Fontes, L. 2010: "Bracara Augusta. Balanço de 30 anos de investigação arqueológica na capital da Galécia romana”, Simulacra ROMAE II. Rome, les capitales de province (capita prouinciarum) et la création d'un espace commum européen. Une approche archéologique, Bulletin de la Societé archéologique champenoise, Mémoire n.19, Reims, 111-124.

Martins, M., Fontes, L., Braga, C., Magalhães, F. e Sendas, J. 2009: Relatório final dos trabalhos arqueológicos realizados no Quarteirão dos CTT
- Avenida da Liberdade, Relatório policopiado, Braga.

Martins, M., Ribeiro, J. e Magalhães, F. 2006: “A arqueologia em Braga e a descoberta do teatro romano de Bracara Augusta", Forum 40, 9-30.

Martins, M., Ribeiro, J., Magalhães, F. e Braga, C. 2012: "Urbanismo e arquitetura de Bracara Augusta. Sociedade, economia e lazer", M. C. Ribeiro y A. Melo (coord.), Evolução da Paisagem Urbana. Sociedade e Economia, Braga, 29-67.

Martins, M., Ribeiro, M.C. e Baptista, J. M. 2011: "As termas públicas de Bracara Augusta e o abastecimento de água da cidade romana", Actas del Seminario Aquae Sacrae. Agua y sacralidad en época antigua, Girona, 69-102.

Morais, R. 2001: "Breve ensaio sobre o anfiteatro de Bracara Augusta", Forum 30, 55-76.

Morais, R. 2005: Autarcia e comércio em Bracara Augusta no período Alto-Imperial: contribuição para o estudo económico da cidade, Bracara Augusta, Escavações Arqueológicas 2, Braga.

Oliveira, E.P. 1978: “O salvamento de Bracara Augusta. IV. Os apontamentos arqueológicos de Braga de José Teixeira”, Minia (2 ${ }^{a}$ série) 1, 20-44.

Palet i Martínez, J. M. 1994: "Estudi territorial del Pla de Barcelona. Estructuració i evolución del territorio entre l'època iberoromana i l'altmedieval segles II-I a.C. - X-XI d.C.", Estudis i Memòries d'Arqueologia de Barcelona, Barcelona.

Pérez Losada, F. 1987: "Sobre el concepto de "villa" no mundo romano", Cadernos de Arqueologia de Braga 4, 79-110.

Pérez Losada, F. 1996: "Hacia una definición de los asentamientos rurales en la Gallaecia: poblados (vici) y casas de campo (villae)", C. Férnandez Ochoa (ed.), Los finisterres atlânticos en la Antigüedad. Época Prerromana y Romana. Actas del Coloquio Internacional, Gijón, 189-197.

Portet, P. 2004: Bertrand Boysset, la vie et les cuvres techniques d'un arpenteur médiéval (v. 1355 v.1416). Paris.

Ribeiro, J. 2010: A Arquitectura romana de Bracara Augusta. Uma análise das técnicas Edilícia, Tese de doutoramento, Braga. http://hdl.handle. net/1822/12232

Ribeiro, M. C. 2008: Braga entre a época romana e a Idade Moderna. Uma metodologia de análise para a leitura da evolução da paisagem urbana, Tese de doutoramento, Braga. http://hdl.handle. net/8113/4

Rodríguez Colmenero, A., Ferrer Sierra, S. e Alvarez Asorey, R.D. 2004: Callaeciae et Asturiae Itinera Romana. Miliarios e outras inscricións 
viárias romanas do Noroeste Hispânico (Conventos Bracarense, Lucense e Asturicense), Santiago de Compostela.

Santos, L. A., Le Roux, P. e Tranoy, A. 1983: "Inscrições romanas do Museu Pio XII em Braga", Bracara Augusta 37, 83-84 (96-97), 183-205.

Silva, P. 2002: As termas romanas de Bracara Augusta, Porto.

Teixeira, C. e Medeiros, J.R.M. 1973: Carta geológica de Portugal (1/50.000). Notícia explicativa da Folha 5-D, Braga, Lisboa.

Tranoy, A. 1981: La Galice romaine: Recherches sur le Nord-Ouest de la Péninsule Ibérique dans l'Antiquité, Paris.

Tranoy, A. 1995-96: "La route, image et instrument du pouvoir impérial dans le nord-ouest ibérique", Cadernos de Arqueologia (Série II) 12-13, 3137.

Tranoy, A. e Le Roux, P. 1989/90: “As necrópoles romanas de Bracara Augusta - Les inscriptions funéraires", Cadernos de Arqueologia 6-7, 183-230.

Trément, F. e Carvalho, H. (no prelo): "Romanisation et développement: approche comparée des territoires des Bracari (Tarraconaise) et des Arverni (Aquitaine). Une perspective de longue durée (IIe s. av. J.C.-IIe s. ap. J.C.)", Simposi Internacional L'Ager Tarraconensis. Paisatge, poblament, cultura material $i$ historia, Tarragona.

VV.AA. 1989: Misurare la terra: centuriazione e coloni nel mondo romano, il caso veneto, Modena.

Recibido: 13-01-2011

Aceptado: 01-07-2011 